\title{
Effect of Nanozinc Supplementation on Haematological and Blood Biochemical Profiles in Goats
}

\author{
P. S. Swain ${ }^{1,2 *}$, S. B. N. Rao ${ }^{1}$, D. Rajendran ${ }^{1}$, K. T. Poornachandra ${ }^{2}$, \\ E. Lokesha ${ }^{2}$ and R. Dhinesh Kumar ${ }^{2}$ \\ ${ }^{1}$ ICAR-National Institute of Animal Nutrition and Physiology, Bangalore, 560030, India \\ ${ }^{2}$ Dairy Cattle Nutrition Division, ICAR-National Dairy Research Institute, Karnal, \\ Haryana, 132001, India \\ *Corresponding author
}

\section{A B S T R A C T}

\section{Keywords}

Blood biochemistry;

Goats;

Haematology; Nano zinc; Zinc Oxide.

Article Info

Accepted:

24 August 2019

Available Online:

10 September 2019
A study was conducted to evaluate the efficiency of nano zinc (NZn) as feed supplementation on haematological and blood biochemical profiles in goats (Capra hircus). $\mathrm{NZn}$ was synthesized by from $0.45 \mathrm{M}$ aqueous solution of zinc nitrate $\left[\mathrm{Zn}\left(\mathrm{NO}_{3}\right)_{2} \cdot 6 \mathrm{H}_{2} \mathrm{O}\right]$ and $0.9 \mathrm{M}$ aqueous solution of sodium hydroxide $(\mathrm{NaOH})$. The particle size thus obtained was $74 \mathrm{~nm}$ and later it was confirmed to be zinc by using TEM-EDAX. Twenty four male goats were divided into 4 groups on the basis of body weight and were supplemented with either basal diet i.e. Concentrate mixture and finger millet (Eleusine corocana) straw @ 50: 50 ratio (BD) which was considered as Negative control (NC), BD with $50 \mathrm{mg} / \mathrm{kg}$ zinc from inorganic $\mathrm{ZnO}$ (IZn-50), BD with $50 \mathrm{mg} / \mathrm{kg}$ zinc from NZnO (NZn-50) or BD with $25 \mathrm{mg} / \mathrm{kg}$ zinc from NZnO (NZn-25) for about 4 months. Supplementation of zinc from either inorganic or nano $\mathrm{Zn}$ had no effect $(\mathrm{P}>0.05)$ on $\mathrm{RBC}$ $\left(10^{6} / \mu \mathrm{l}\right)$, WBC $\left(10^{3} / \mu \mathrm{l}\right), \mathrm{PCV}(\%)$, neutrophil (\%), lymphocytes (\%), eisonophil (\%), monocyte (\%), haemoglobin (g/dL), ALT (IU/L), AST (IU/L), ALP (IU/L) and creatinine (mg/DL) levels of goat blood. However, globulin $(\mathrm{g} / \mathrm{dL})$ and total protein $(\mathrm{g} / \mathrm{dL})$ varied significantly among the treatment groups $(\mathrm{P}<0.01)$ without affecting blood albumin $(\mathrm{g} / \mathrm{dL})$ and $\mathrm{A} / \mathrm{G}$ ratio levels $(\mathrm{P}>0.05)$. The globulin level was more $(\mathrm{P}<0.01)$ in NZn-50 compared to both NC and IZn-50. Total protein $(\mathrm{g} / \mathrm{dL})$ was more $(\mathrm{P}<0.001)$ in NZn-50 which varied

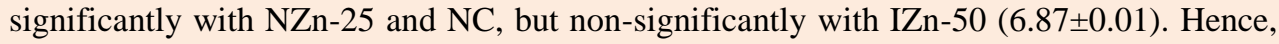
zinc supplementation in form of nano zinc improved globulin and total protein significantly without affecting other haematological and blood biochemical parameters in goats, which may be attributed to its better bioavailability than its inorganic counterpart.

\section{Introduction}

Zinc $(\mathrm{Zn})$ is the second most abundant trace element in the animal body, but it can't be stored (Zalewski et al., 2005), so regular dietary intake is necessary to meet the normal physiology of the animals. Zinc, as a component of multiple enzymes of the animal, plays a pivotal role in the animal physiology (Swain et al., 2016). Rats and humans are 
susceptible to even marginal $\mathrm{Zn}$ deficiency which reduces immune responses (Fraker et al., 1984). Someya et al., (2007) observed that dietary zinc deficiency increased the number of basophils, eosinophils and neutrophils and decreased the number of lymphocytes, suggesting the change in white blood cell distribution. Miller et al., (1965) reported that, serum ALP decreases in Zn deficiency which is used as an indicator of animal $\mathrm{Zn}$ status.

The $\mathrm{Zn}$ can be supplemented through feed, either from inorganic, organic or nano source. The $\mathrm{Zn}$ of nanometer dimension is called as nanoZn (NZn). At this scale the physical, chemical and biological properties of material differ fundamentally and often unexpectedly. The applications of nano materials in agriculture and animal husbandry are very important as Indian economy predominantly depends on agriculture (Sri Sindhura et al., 2014). These NP are having higher potential than their conventional sources and thus reduce the quantity required (Sri Sindhura et al., 2014). Zinc Oxide (ZnO) NP can efficiently be synthesized by using any of physical, chemical or biological methods (Swain et al., 2015) which are cheap and easy (Swain et al., 2016). Swain et al., (2018a) reported that supplementation of NZn affects rumen fermentation in goats without affecting rumen VFA profile, rumen soluble $\mathrm{Zn}$ content in goats. The experimental results pertaining to haematological and biochemical profiles of goats receiving two levels of Nano Zinc (25 and $50 \mathrm{ppm}$ ) compared to Inorganic Zinc (50 $\mathrm{ppm}$ ) and no added zinc (NC) were discussed in this research paper.

\section{Materials and Methods}

\section{Synthesis and characterization of NZn particle}

The nano zinc (NZn) particles were synthesized and characterized (Swain et al., 2018a,b) at Department of Nano Science and Technology, TNAU, Coimbatore. The particle size was found to be $74 \mathrm{~nm}$ by XRD.

\section{Animal management}

Twenty four non-descriptive local breed goats $(18.7 \pm 0.33 \mathrm{~kg})$ were divided into four groups of six animals and maintained under uniform management conditions throughout the experimental period. Goats were housed in a well ventilated with individual feeding and watering facilities. All the goats were dewormed and vaccinated against enterotoxemia and peste des petites ruminats (PPR).

Animals were fed with a concentrate mixture [having ingredient composition of Maize (Zea mays), $40 \%$; soybean (Glycine max) meal, 35 $\%$; rice (Oryza sativa) bran, $22 \%$; mineral Mixture, $2 \%$ and salt, $1 \%$ ] and finger millet straw (Eleusine corocana) at 50:50 ratio as per ICAR (2013). All the animals were fed at 3\% of their body weight throughout the experiment period, which was adjusted every fortnight. A mineral mixture was prepared as per the ICAR (2013) recommendations except that of the zinc. All the animals under different treatment group were provided with the same basal diet comprising of concentrate and straw at 50:50 ratio, quantified as per their body weight, only variable being the source and quantity of zinc which was fed orally as a paper capsule (cellulose paper, 75 GSM), daily.

\section{Collection and processing of the samples}

The blood was collected by jugular vein puncture before feeding on $90^{\text {th }}$ day of experimental feeding and $2 \mathrm{~mL}$ was transferred to a heparinised vacutainer tubes and $5 \mathrm{~mL}$ was transferred into a $10 \mathrm{~mL}$ vacutainer tube for separation of serum to assess the haematological parameters. Then 
the blood samples kept for serum collection were kept undisturbed for $2 \mathrm{~h}$ to facilitate clotting, and then centrifuged at $3000 \mathrm{rpm}$ at $4^{\circ} \mathrm{C}$ for $20 \mathrm{~min}$. A clear supernatant (sera) was separated and stored in deep freeze $\left(-20^{\circ} \mathrm{C}\right)$ for blood biochemical analyses.

\section{Estimation of haematology and blood biochemical profiles}

Heparinised blood samples were analysed for its haematological parameters by using autoanalyser (Erba chem 5 plus, Germany).

The serum samples collected after experimental feeding were analysed to determine the different blood biochemical constituents like ALP, blood urea nitrogen were done by following the protocols of Erba diagnostic Mannheim $\mathrm{GmbH}$ (Germany) by using Alere (AM 2100) Micropate reader by following respective kit protocols (ERBA diagnostics Mannheim GmbH, Germany) and albumin, globulin, total protein, creatinine, AST, ALT done by using M/s. Span Diagnostics Limited, Surat, India. The serum biochemical estimations were carried out using Semiauto analyzer, Biosystems (BTS 320). Serum total protein (TP) and albumin were estimated by Biuret and BCG dye binding method (Dumas et al., 1971). Globulin was calculated by subtracting serum albumin from TP and expressed as g/dl blood serum. Albumin to globulin ratio is mere the ratio of albumin and globulin in the blood of individual animal. Blood urea nitrogen (BUN) level in the serum samples were determined by following the methodology of Talke and Schubert (1965) and Tiffany et al., (1972) and expressed as $\mathrm{mg} / \mathrm{dL}$. Creatinine content in the serum, expressed as $\mathrm{mg} / \mathrm{dL}$, was determined by the alkaline picrate method of Bonses and Taussky (1945), where the creatinine in the protein-free solution was allowed to react with alkaline picrate to produce a red colour complex, which was subsequently measured colorimetrically at $520 \mathrm{~nm}$. Alanine aminotransferase (ALT) was estimated by the method described by Reitman and Frankel (1957) using diagnostic kit (manufactured by Span Diagnostic Limited, Surat, India). Aspartate aminotransferase (AST) in blood serum was determined as per the method given by Reitman and Frankel (1957) using diagnostic kits manufactured by Span Diagnostic Limited, Surat, India. Alkaline phosphatase (ALP, U/L) was estimated in the serum samples by using Wilkinson et al., (1969) which is a modification of Bessey et al., (1946) method.

\section{Statistical Analysis}

Data obtained on various parameters were subjected to one way analysis of variance (Snedecor and Cochran, 1994). The statistical software SPSS (SPSS Inc., Chicago, IL, USA) was used for analysis of data and analysis of variance assuming for independent constant variance structure with post-hoc Duncan to find the pair wise significance between treatments. Results were expressed as mean \pm S.E. A P-value of less than or equal to 0.05 was accepted to indicate statistical significance.

\section{Results and Discussion}

\section{Haematological profiles}

Effect of supplementation of graded doses of $\mathrm{NZn}$ on haematological profiles of goats is depicted in Table 1. It was observed that RBC $\left(10^{6} / \mu \mathrm{l}\right), \mathrm{WBC}\left(10^{3} / \mu \mathrm{l}\right), \mathrm{PCV}(\%)$, neutrophil (\%), lymphocytes (\%), eisonophil (\%), monocyte $(\%)$ and haemoglobin (g/dL) level in the goat blood did not differ statistically $(\mathrm{P}>0.05)$ by $\mathrm{IZn}$ and $\mathrm{NZn}$ supplementation in goats. The RBC $\left(10^{6} / \mu \mathrm{l}\right)$ was ranging from $17.4 \pm 0.55$ (NC) and $17.4 \pm 0.60$ (IZn-50) to $18.9 \pm 0.76 \mathrm{NZn}-50$. The WBC $\left(10^{3} / \mu \mathrm{l}\right)$ count was $16.5 \pm 1.93,15.0 \pm 1.98,16.5 \pm 1.34$ and 
$13.9 \pm 2.12$, respectively in NC, IZn-50, NZn50 and NZn-25 groups. The PCV (\%) was found in the range of $27.2 \pm 0.64$ (NC) to $28.1 \pm 0.81$ (NZn-50). The differential count of WBC was also found to be same across the treatment groups $(\mathrm{P}>0.05)$. Neutrophils (\%) were found in the range of $38.0 \pm 3.49(\mathrm{NZn}-$ $25)$ to $52.4 \pm 8.45$ (NC). Proportion of lymphocytes $(\%)$ ranged from $44.2 \pm 9.00$ in $\mathrm{NC}$ to $58.2 \pm 3.48$ in NZn-25. Eosinophil (\%) ranged from $1.20 \pm 0.20$ in NZn-50 to $3.80 \pm 1.59$ in IZn-50. Monocytes (\%) ranged from $0.80 \pm 0.37$ in $\mathrm{NZn}-50$ to $1.40 \pm 0.24$ in IZn-50. The haemoglobin $(\mathrm{g} / \mathrm{dL})$ was found to be similar among the treatment groups within a range of $8.50 \pm 0.19$ in $\mathrm{NC}$ to $8.90 \pm 0.21$ in NZn-50.

Results indicated that supplementation of zinc did not affect $(\mathrm{P}>0.05)$ the haematological profiles of the goats compared to NC. PCV $(\%)$, eosinophil (\%), monocyte (\%) and haemoglobin $(\mathrm{g} / \mathrm{dL})$ were found in the normal reference range given by Feldman et al., (2002), whereas RBC $\left(10^{6} / \mu \mathrm{l}\right)$ was within the normal range in NC, IZn-50 and NZn- 25, but NZn-50 showed marginally higher RBC than the reference values by Feldman et al., (2002). WBC $\left(10^{3} / \mu \mathrm{l}\right)$ was found to be marginally higher than the reported values by Feldman et al., (2002). Lymphocytes (\%) in NC, IZn-50 and NZn-50 were lower than reported values of Feldman et al., (2002), whereas NZn-25 was within the range. Nagalakshmi et al., (2015) reported similar WBC, RBC, haemoglobin concentration, PCV, mean corpuscular volume, lymphocyte, monocyte, and granulocyte concentration among the rats fed inorganic $\left(\mathrm{ZnCO}_{3}\right)$ and organic (Zn-nic; 6, 9, and 12 ppm) sources. Kegley et al., (2001) also reported similar total WBC by supplementing $360 \mathrm{mg} \mathrm{Zn/d}$ either as $\mathrm{ZnSO}_{4}$ or Zn-amino acid complex along with either Bermuda grass hay (21 mg $\mathrm{Zn} / \mathrm{kg} \mathrm{DM}$ ) or control diet (38 mg Zn/kg DM) in beef calves and heifers. Mandal and Das (2010) reported similar haemoglobin concentration and packed cell volume (PCV) in crossbred calves after supplementing $35 \mathrm{mg} / \mathrm{kg}$ of $\mathrm{Zn}$ as zinc sulphate or zinc propionate to the basal diet (32.5 mg Zn/kg DM). Donmez et al., (2002) also reported that supplementation of 0,125 , 500 and $1000 \mathrm{mg} \mathrm{Zn}$ per $\mathrm{kg}$ of drinking water in broiler chicks had no effect on erythrocyte count (RBC), hemoglobin, hematocrit, total leucocytes and differential leucocyte count (DLC), which is in accordance with the present findings in goats.

On the contrary, Sobhanirad and Naserian (2012) reported higher number of RBC, haemoglobin concentration, packed cell volume, and mean corpuscular hemoglobin concentration in the $\mathrm{Zn}$-Met than control and $\mathrm{ZnSO}_{4} \quad$ supplemented group after supplementing $500 \mathrm{mg} \mathrm{Zn} / \mathrm{kg}$ DM from either $\mathrm{ZnSO}_{4} \cdot \mathrm{H}_{2} \mathrm{O}$ or $\mathrm{ZnMet}$ in Holstein cows. Akbari et al., (2008) observed that addition of $60 \mathrm{mg} \mathrm{Zn/kg}$ basal diet from $\mathrm{ZnO}$ significantly $(\mathrm{P}<0.05)$ increased $\mathrm{WBC}$ and lymphocyte count with no effect on RBC count and haemoglobin in broiler chicken (21 days). It has been reported that dietary zinc deficiency increased the number of basophils, eosinophils and neutrophils and decreased the number of lymphocytes, suggesting the change in white blood cell distribution (Someya et al., 2007), which was not observed in the NC which suggests that the Zinc level (17.8 ppm) in BD was sufficient for minimum requirement of the goats under trial. Haematological profiles recorded in different treatment groups were similar found to be in normal ranges.

\section{Blood biochemical profiles}

The effect of supplementation of graded doses of NZn on blood biochemical profiles of goats is shown in Table 2. ALT (IU/L) was found similar $(\mathrm{P}>0.05)$ in all the groups $(16.0 \pm 3.76$ in IZn-50 to $21.9 \pm 1.64$ in NC). AST (IU/L) level in goats was also similar $((\mathrm{P}>0.05)$ 
which varied from $197 \pm 5.14$ (NC) to 229 \pm 17.6 (IZn-50). Similarly, ALP (IU/L) and creatinine $(\mathrm{mg} / \mathrm{dL})$ levels were also similar $(\mathrm{P}<0.05)$ among the treatment groups. ALP was more in NZn-50 (378 \pm 45.7$)$ and minimum in $\mathrm{NC}(285 \pm 61.3)$. Creatinine level varied from $1.10 \pm 0.14$ (NC) to $1.37 \pm 0.14$ (NZn-25) among different treatment groups.

The blood albumin (g/dL) was found to be similar $(\mathrm{P}>0.05)$ among the treatment groups whereas, globulin $(\mathrm{g} / \mathrm{dL})$ and total protein $(\mathrm{g} / \mathrm{dL})$ varied significantly $(\mathrm{P}<0.01)$. Albumin level varied between $3.66 \pm 0.03$ (NC) to $3.72 \pm 0.02$ (IZn-50). The globulin level was more in NZn-50 (3.20 \pm 0.02$)$ which varied significantly $(\mathrm{P}<0.01)$ with both $\mathrm{NC}$ and IZn50. The NZn-25 (3.17 \pm 0.02$)$ remained intermediate in globulin level. Similar to globulin, total protein (g/dL) was more $(\mathrm{P}<0.001)$ in $\mathrm{NZn}-50 \quad(6.90 \pm 0.01)$ which varied significantly with NZn-25 $(6.85 \pm 0.01)$ and $\mathrm{NC}(6.78 \pm 0.03)$, but non-significantly with IZn-50 (6.87 \pm 0.01$)$. Albumin: globulin ratio was similar $(\mathrm{P}>0.05)$ in all the groups which ranged from 1.16 \pm 0.01 (NZn-50 and NZn-25) to $1.18 \pm 0.01$ (IZn-50).

In the present study, blood enzymes such as ALT, AST and ALP (IU/L) were similar in all the groups. The values obtained in the present study were in physiological ranges suggested by Kaneko et al., (2008). Results obtained in the present study are in concordance with Mandal et al., (2008) in cross bred calves, Hassan et al., (2011) in adult Bakri sheep and Kwiecien et al., (2017) in broiler chicken with supplementation of zinc.

Contrary to the present findings obtained in the study, Spears (1989) in heifers, Jia et al., (2009) in Cashmere goats, Nagalakshmi et al., (2009) in Nellore lambs suggested increase in ALP whereas, Gaafar et al., (2011) reported decrease of ALP due to supplementation of graded levels of zinc from organic or inorganic sources. Serum ALP is a $\mathrm{Zn}$ metalloenzyme that decreases in Zn deficiency and serum ALP activity is used as an indicator of animal $\mathrm{Zn}$ status (Miller et al., 1965), which was not observed in the present study which is an indication that the zinc level of the basal diet (NC) was not deficient enough to bring the changes in serum ALP level in the present study. Creatinine (mg/dL), total protein, albumin $(\mathrm{g} / \mathrm{dL})$ obtained in the present study are in physiological ranges suggested by Kaneko et al., (2008).

There is no effect of treatment on creatinine levels obtained in the study. Total Protein and globulin $(\mathrm{g} / \mathrm{dL})$ levels were found to be more in NZn supplemented at $50 \mathrm{mg} / \mathrm{kg}$ feed group. Similar to the present study, Daghash and Mousa (1999) in buffalo calves observed increased protein levels due to zinc supplementation.

However, Nagalakshmi et al., (2009) observed similar protein levels and increased globulin levels in lambs fed inorganic or organic zinc sources at $30 \mathrm{ppm}$. Huerta et al., (2002) did not find any change in plasma protein and blood urea-N concentration in beef steers with zinc supplementation even at 200 ppm.

Similarly, Hassan et al., (2011) in adult Bakri sheep found similar serum total protein, albumin and creatinine. Very scanty literature is available on effects of feeding NZn as feed supplement. At higher doses, serum ALT, AST and ALP contents were elevated in mice with $\mathrm{NZnO}$ treated groups than control (Jung et al., 2010; Sharma et al., 2012). The proposed mechanism may be due to the fact that, the NZn is much more active and can be rapidly transformed into respective ions in gastric juice. So large amounts of metal ions are generated and subsequently brought to liver and kidney for metabolism and excretion, which might cause damage to hepatic and renal tissues (Chen et al., 2007). 
Table.1 Effect of supplementation of two levels of NZn (50 and $25 \mathrm{mg} / \mathrm{kg}$ ) on haematology of goats

\begin{tabular}{|c|c|c|c|c|c|c|c|}
\hline Attributes & NC & IZn-50 & NZn-50 & NZn-25 & $\begin{array}{l}\text { Reference } \\
\text { values* }\end{array}$ & SEM & $\mathbf{P}$ \\
\hline $\operatorname{RBC}\left(10^{6} / \mu \mathrm{l}\right)$ & $\begin{array}{l}17.4 \\
\pm 0.55\end{array}$ & $\begin{array}{l}17.4 \\
\pm 0.60\end{array}$ & $\begin{array}{l}18.9 \\
\pm 0.76\end{array}$ & $\begin{array}{l}17.7 \\
\pm 0.71\end{array}$ & $8-18$ & 0.34 & 0.714 \\
\hline $\mathrm{WBC}\left(10^{3} / \mu \mathrm{l}\right)$ & $\begin{array}{l}16.5 \\
\pm 1.93\end{array}$ & $\begin{array}{l}15.0 \\
\pm 1.98\end{array}$ & $\begin{array}{l}16.5 \\
\pm 1.34\end{array}$ & $\begin{array}{l}13.9 \\
\pm 2.12\end{array}$ & $4-13$ & 0.88 & 0.344 \\
\hline $\operatorname{PCV}(\%)$ & $\begin{array}{l}27.2 \\
\pm 0.64\end{array}$ & $\begin{array}{l}28.0 \\
\pm 0.98\end{array}$ & $\begin{array}{l}28.1 \\
\pm 0.81\end{array}$ & $\begin{array}{l}27.6 \\
\pm 0.89\end{array}$ & $22-38$ & 0.39 & 0.875 \\
\hline Neutrophil (\%) & $\begin{array}{l}52.4 \\
\pm 8.45\end{array}$ & $\begin{array}{l}48.8 \\
\pm 6.41\end{array}$ & $\begin{array}{l}50.0 \\
\pm 5.28\end{array}$ & $\begin{array}{l}38.0 \\
\pm 3.49\end{array}$ & $30-48$ & 3.11 & 0.391 \\
\hline Lymphocytes (\%) & $\begin{array}{l}44.2 \\
\pm 9.00\end{array}$ & $\begin{array}{l}46.0 \\
\pm 5.81\end{array}$ & $\begin{array}{l}48.0 \\
\pm 5.62\end{array}$ & $\begin{array}{l}58.2 \\
\pm 3.48\end{array}$ & $50-70$ & 3.15 & 0.423 \\
\hline Eisonophil (\%) & $\begin{array}{l}2.40 \\
\pm 0.98\end{array}$ & $\begin{array}{l}3.80 \\
\pm 1.59\end{array}$ & $\begin{array}{l}1.20 \\
\pm 0.20\end{array}$ & $\begin{array}{l}2.60 \\
\pm 0.51\end{array}$ & $1-8$ & 0.49 & 0.344 \\
\hline Monocyte (\%) & $\begin{array}{l}1.00 \\
\pm 0.00\end{array}$ & $\begin{array}{l}1.40 \\
\pm 0.24\end{array}$ & $\begin{array}{l}0.80 \\
\pm 0.37\end{array}$ & $\begin{array}{l}1.20 \\
\pm 0.20\end{array}$ & $0-4$ & 0.12 & 0.374 \\
\hline Haemoglobin (g/dL) & $\begin{array}{l}8.50 \\
\pm 0.19\end{array}$ & $\begin{array}{l}8.68 \\
\pm 0.28\end{array}$ & $\begin{array}{l}8.90 \\
\pm 0.21\end{array}$ & $\begin{array}{l}8.50 \\
\pm 0.11\end{array}$ & $4-13$ & 0.10 & 0.493 \\
\hline
\end{tabular}

Each value is an average of six observations. *Feldman et al., (2002).

Table.2 Effect of supplementation of graded doses of NZn (50 and $25 \mathrm{mg} / \mathrm{kg})$ on blood biochemical profiles in goats

\begin{tabular}{|l|c|c|c|c|c|c|}
\hline Attributes & NC & IZn-50 & NZn-50 & NZn-25 & SEM & P \\
\hline ALT & 21.9 & 16.0 & 19.9 & 17.3 & 1.17 & 0.298 \\
(IU/L) & \pm 1.64 & \pm 3.76 & \pm 0.66 & \pm 1.89 & & \\
\hline AST & 197 & 229 & 207 & 198 & 7.07 & 0.374 \\
(IU/L) & \pm 5.14 & \pm 17.6 & \pm 20.3 & \pm 6.19 & & \\
\hline ALP & 285 & 353 & 378 & 356 & 26.1 & 0.657 \\
(IU/L) & \pm 61.3 & \pm 61.9 & \pm 45.7 & \pm 44.9 & & \\
\hline Creatinine & 1.10 & 1.16 & 1.21 & 1.37 & 0.06 & 0.413 \\
(mg/dL) & \pm 0.14 & \pm 0.10 & \pm 0.09 & \pm 0.14 & & \\
\hline Albumin & 3.66 & 3.72 & 3.69 & 3.67 & 0.01 & 0.207 \\
(g/dL) & \pm 0.03 & \pm 0.02 & \pm 0.02 & \pm 0.02 & & \\
\hline Globulin & $3.12^{\mathrm{b}}$ & $3.14^{\mathrm{b}}$ & $3.20^{\mathrm{a}}$ & $3.17^{\mathrm{ab}}$ & 0.01 & 0.009 \\
(g/dL) & \pm 0.02 & \pm 0.02 & \pm 0.02 & \pm 0.02 & & \\
\hline Total protein & $6.78^{\mathrm{c}}$ & $6.87^{\mathrm{ab}}$ & $6.90^{\mathrm{a}}$ & $6.85^{\mathrm{b}}$ & 0.01 & 0.000 \\
(g/dL) & \pm 0.03 & \pm 0.01 & \pm 0.01 & \pm 0.01 & & \\
\hline Albumin: & 1.17 & 1.18 & 1.16 & 1.16 & 0.01 & 0.318 \\
Globulin & \pm 0.01 & \pm 0.01 & \pm 0.01 & \pm 0.01 & & \\
\hline
\end{tabular}

${ }^{a, b, c}$ Means with different superscripts in a row differs $(\mathrm{P}<0.05)$ significantly. Each value is an average of six observations. 
Thus, results indicated that supplementation of zinc especially NZn caused improvement in total protein and globulin concentrations without affecting albumin level in goats.

Zinc supplementation in form of nano zinc improved globulin and total protein significantly without affecting other haematological parameters like RBC $\left(10^{6} / \mu 1\right)$, $\operatorname{WBC}\left(10^{3} / \mu \mathrm{l}\right)$, PCV (\%), neutrophil (\%), lymphocytes $(\%)$, eisonophil (\%), monocyte (\%), haemoglobin (g/dL) as well as blood biochemical parameters like ALT (IU/L), AST (IU/L), ALP (IU/L) and creatinine in goats, which may be attributed to its better bioavailability than its inorganic counterpart.

\section{Acknowledgements}

The authors gratefully acknowledge former and present Directors of ICAR-National Dairy Research Institute, Karnal and Head, Southern Regional Station, ICAR-National Dairy Research Institute, Bengaluru for providing necessary support during the course of study. The authors acknowledge Director, ICARNational Institute of Animal Nutrition and Physiology, Bengaluru, India for providing necessary facilities during the course of research at ICAR- National Institute of Animal Nutrition and Physiology, Bengaluru.

\section{References}

Akbari, M.R., Kermanshahi, H., Moghaddam, H.N., Moussavi, A.H. and Afshari, J.T., 2008. Effects of wheat-soybean meal based diet supplementation with vitamin $\mathrm{A}$, vitamin $\mathrm{E}$ and zinc on blood cells, organ weights and humoral immune response in broiler chickens. Journal of Animal and Veterinary Advances, 7(3), pp.297-304

Bessey, O.A., Lowky, O.H. and Brock, M.J., 1946. A method for the rapid determination of alkaline phosphatase with five cubic millimeters of serum. Journal of Biological Chemistry, 164, pp.321-329.
Bonses, R. and Taussky, H.H., 1945. On the colorimetric determination of creatmine by the Jatfe reaction. Journal of Biological Chemistry, 158, pp.581-591.

Chen, Z., Meng, H., Xing, G., Chen, C. and Zhao, Y., 2007. Toxicological and biological effects of nanomaterials. International Journal of Nanotechnology, 4(1-2), pp.179-196.

Daghsh, H.A. and Mousa, S.M., 1999. Zinc sulfate supplementation to ruminant rations and its effects on digestibility in lambs; growth, rectal temperature and some blood constituents in buffalo calves under heat stress. Assiut Veterinary Medical Journal, 40, pp.128-146.

Donmez, N., Donmez, H.H., Keskin, E. and Çelik, I., 2002. Effects of zinc supplementation to ration on some hematological parameters in broiler chicks. Biological Trace Element Research, 87(1-3), p.125.

Dumas, B.T., Waston, W.A. and Biggs, H.G., 1971. Determination of total protein and albumin in serum. Clinica Chimica Acta, 31, pp.87-96.

Feldman, B.F., Zink, J.G. and Jain, N.C., 2002. Schalm's Veterinary Hemetology. Philadelphia. Baltimore, New York, London, Buenos Aires, Hong Kong, Sidney.

Fraker, P.J., Hildebrandt, K. and Luecke, R.W., 1984. Alteration of antibody-mediated responses of suckling mice to T-celldependent and independent antigens by maternal marginal zinc deficiency: restoration of responsivity by nutritional repletion. The Journal of Nutrition, 114(1), pp.170-179.

Gaafar, H.M.A., Bassiouni, M.I., Ali, M.F.E., Shitta, A.A. and Shamas, A.S.E., 2011. Effect of zinc methionine supplementation on productive performance of lactating Friesian cows. Journal of Animal Science, 2, p.006.

Hassan, A.A., Ashry, G.M.E. and Soliman, S.M., 2011. Effect of supplementation of chelated zinc on milk production in ewes. Food and Nutrition Sciences, 2, pp.706713.

Huerta, M., Kincaid, R.L., Cronrath, J.D., Busboom, J., Johnson, A.B. and Swenson, 
C.K., 2002. Interaction of dietary zinc and growth implants on weight gain, carcass traits and zinc in tissues of growing beef steers and heifers. Animal Feed Science and Technology, 95(1), pp.15-32.

ICAR, 2013. Nutrient Requirements of sheep, goat and rabbit, Indian Council of Agricultural Research, New Delhi and National Institute of Animal Nutrition and Physiology, Bangalore, India, 2013.

Jia, W., Zhu, X., Zhang, W., Cheng, J., Guo, C. and Jia, Z., 2009. Effects of source of supplemental zinc on performance, nutrient digestibility and plasma mineral profile in Cashmere goats. AsianAustralasian Journal of Animal Sciences, 22, pp.1648-1653

Jung, W.C., Kim, S. and Lee, H.J., 2010. Acute Toxicity of Nano-Scale Zinc Oxide Powder in ICR Mice. Journal of Biomedical Research, 11(4), pp.219-224.

Kaneko, J.J., Harvey, J.W. and Bruss, M.L. eds., 2008. Clinical Biochemistry of Domestic Animals. $8^{\text {th }}$ Ed. Academic press. pp-882904.

Kegley, E.B., Silzell, S.A., Kreider, D.L., Galloway, D.L., Coffey, K.P., Hornsby, J.A. and Hubbell, D.S., 2001. The Immune Response and Performance of Calves Supplemented with Zinc from an Organic and an Inorganic Source11Published with the approval of the director of the Arkansas Agricultural Experiment Station, manuscript no. 00075. The Professional Animal Scientist, 17(1), pp.33-38.

Kwiecien, M., Winiarska-Mieczan, A., Milczarek, A. and Klebaniuk, R., 2017. Biological Response of Broiler Chickens to Decreasing Dietary Inclusion Levels of Zinc Glycine Chelate. Biological Trace Element Research, 175(1), pp.204-213.

Mandal, G.P. and Dass, R.S., 2010. Haematobiochemical profile of crossbred calves supplemented with inorganic and organic source of zinc. Indian Journal of Animal Research, 44(3),pp.197-200.

Mandal, G.P., Dass, R.S., Garg, A.K., Varshney, V.P. and Mondal, A.B., 2008. Effect of zinc supplementation from inorganic and organic sources on growth and blood biochemical profile in crossbred calves.
Journal of Animal and Feed Sciences, 17(2), pp.147-156.

Miller, W.J., Pitts, W.J., Clifton, C.M. and Morton, J.D., 1965. Effects of Zinc Deficiency per se on Feed Efficiency, Serum Alkaline Phosphatase, Zinc in Skin, Behavior, Greying, and other Measurements in the Holstein Calf1. Journal of Dairy Science, 48(10), pp.1329-1334.

Moghaddam, A.B., Nazari, T., Badraghi, J. and Kazemzad, M., 2009. Synthesis of $\mathrm{ZnO}$ nanoparticles and electrodeposition of polypyrrole/ZnO nanocomposite film. International Journal of Electrochemical Science, 4(2), pp.247-257.Nagalakshmi et al., (2009 b)

Nagalakshmi, D., Dhanalakshmi, K. and Himabindu, D., 2009. Effect of dose and source of supplemental zinc on immune response and oxidative enzymes in lambs. Veterinary research communications, 33(7), pp.631-644.

Nagalakshmi, D., Sridhar, K. and Parashuramulu, S., 2015. Replacement of inorganic zinc with lower levels of organic zinc (zinc nicotinate) on performance, hematological and serum biochemical constituents, antioxidants status, and immune responses in rats. Veterinary World, 8(9), p.11561162.

Reitman, S. and Frankel, S., 1957. A colorimetric method for determination of serum glutamate oxaloacetate and glutamic pyruvate transaminase. American Journal of Clinical Pathology, 28, pp.56-58.

Sharma, V., Singh, P., Pandey, A.K. and Dhawan, A., 2012. Induction of oxidative stress, DNA damage and apoptosis in mouse liver after sub-acute oral exposure to zinc oxide nanoparticles. Mutation Research/Genetic Toxicology and Environmental Mutagenesis, 745(1), pp.84-91.

Snedecor, G.W. and Cochran, W.G., 1994. Statistical methods. 8. USA: Iowa State Univeristy Press.

Sobhanirad, S. and Naserian, A.A., 2012. Effects of high dietary zinc concentration and zinc sources on hematology and biochemistry of blood serum in Holstein dairy cows. Animal Feed Science and 
Technology, 177(3), pp.242-246.

Someya, Y., Ichinose, T., Nomura, S., Kawashima, Y.U., Sugiyama, M., Tachiyashiki, K. and Imaizumi, K., 2007. Effects of zinc deficiency on the number of white blood cells in rats. The FASEB Journal, 21(5), pp.A719-A719.

Spears, J.W., 1989. Zinc methionine for ruminants: relative bioavailability of zinc in lambs and effects of growth and performance of growing heifers. Journal of Animal Science, 67(3), pp.835-843.

Sri Sindhura, K., Prasad, T.N.V.K.V., Selvam, P.P. and Hussain, O.M., 2014. Synthesis, characterization and evaluation of effect of phytogenic zinc nanoparticles on soil exoenzymes. Applied Nanoscience, 4(7), pp.819-827.

Swain, P.S., Rajendran, D., Rao, S.B.N. and Dominic, G., 2015. Preparation and effects of nano mineral particle feeding in livestock: A review. Veterinary World, 8(7), pp.888-891.

Swain, P.S., Rao, S.B., Rajendran, D., Dominic, G. and Selvaraju, S., 2016. Nano zinc, an alternative to conventional zinc as animal feed supplement: A review. Animal Nutrition, 2(3), pp.134-141.

Swain, P.S., Rao, S.B.N., Rajendran, D., Soren, N.M., Pal, D.T. and Bhat, S.K., 2018a. Effect of Supplementation of Nano Zinc on Rumen Fermentation and Fiber
Degradability in Goats. Animal Nutrition and Feed Technology, 18(3), pp.297-309.

Swain, P.S., Rao, S.B.N., Rajendran, D., Pal, D., Mondal, S., \& Selvaraju, S. 2018b. Effect of Supplementation of Nano Zinc Oxide on Nutrient Retention, Organ and Serum Minerals Profile, and Hepatic Metallothionein Gene Expression in Wister Albino Rats. Biological trace element research, 1-11. http://scihub.tw/10.1007/s12011-018-1517-5.

Talke, H.S.G.E. and Schubert, G.E., 1965. Enzymatische Harnstoffbestimmung in Blut und Serum im optischen Test nachWarburg. Journal of Molecular Medicine, 43(3), pp.174-175.

Tiffany, T.O., Jansen, J.M., Burtis, C.A., Overton, J.B. and Scott, C.D., 1972. Enzymatic kinetic rate and end-point analyses of substrate, by use of a GeMSAEC fast analyzer. Clinical Chemistry, 18(8), pp.829-840.

Toraya, H., 1986. Whole-powder-pattern fitting without reference to a structural model: application to X-ray powder diffraction data. Journal of Applied Crystallography, 19(6), pp.440-447.

Wilkinson, J.H., Boutwell, J.H. and Winsten, S., 1969. Evaluation of a new system for the kinetic measurement of serum alkaline phosphatase. Clinical Chemistry, 15(6), pp.487-495.

\section{How to cite this article:}

Swain, P. S., S. B. N. Rao, D. Rajendran, K. T. Poornachandra, E. Lokesha and Dhinesh Kumar, R. 2019. Effect of Nanozinc Supplementation on Haematological and Blood Biochemical Profiles in Goats. Int.J.Curr.Microbiol.App.Sci. 8(09): 2688-2696. doi: https://doi.org/10.20546/ijcmas.2019.809.310 